\title{
The Effectiveness of Price Bands on Emerging Markets:
}

\section{Evidence from India}

\author{
Chakrapani Chaturvedula ${ }^{1} \&$ Nikhil Rastogi ${ }^{1}$ \\ ${ }^{1}$ Professor, Department of Finance \& Accounting, IMT Hyderabad, India \\ Correspondence: Chakrapani Chaturvedula, Professor, Department of Finance and Accounting, IMT Hyderabad, \\ India. E-mail: nrastogi@imthyderabad.edu.in
}

Received: November 4, 2018

Accepted: November 22, 2018

Online Published: November 23, 2018

doi:10.5430/afr.v7n4p195

URL: https://doi.org/10.5430/afr.v7n4p195

\begin{abstract}
We study the impact of price bands in the Indian capital markets and following the methodology of Kim and Rhee (1997) we do not find evidence in support of the volatility spillover hypothesis. Our evidence suggests that price limits does not hinder the price discovery process and may play an important role in reducing the volatility of stock prices in the emerging markets like India.
\end{abstract}

Keywords: price limits, price bands, volatility spillover hypothesis

\section{Introduction}

Stock Market crashes around the world had been frequent across the world. The 1987 crash in the United States and the East Asian financial crisis of 1997 have made stock exchanges and regulators sit up and look at ways to reduce volatility and avoid recurrence of such steep fall in price of securities by incorporating appropriate market stabilization mechanisms. Circuit breakers and price limits are the most frequently used mechanisms by stock exchanges to control volatility. The popularity of these measures can be gauged from the fact that price limits (or Price Bands) are common in many non-US equity markets including Austria, Belgium, France, Greece, India, Italy, Japan, Korea, Malaysia, Mexico, Netherlands, Spain, Switzerland, Taiwan, and Thailand.

Indian markets saw wide swings on May 17 2004, May 22 2006, October 172007 and January 222008 causing the trading to be halted when the Sensex and nifty dropped by more than $10 \%$ in day.

Securities and Exchange Board of India (SEBI), the equivalent of Securities and Exchange commission in USA(SEC), imposes a market wide circuit breaker system which brings about a coordinated trading halt in all equity and equity derivatives markets nation-wide, when the index moves either way by $10 \%, 15 \%$ and $20 \%$. The movement of either indices of Bombay Stock Exchange (BSE) and National Stock Exchange (NSE), whichever is breached earlier, causes the trading to halt. However, in respect of stocks, exchanges have different price bands for different stocks and these bands are regularly updated in their circulars. The limits imposed by the stock exchange segregate the stocks in the different categories on the basis of their respective price bands. The price bands being followed by the national stock exchange since year 2003 are 2\%,5\%,10\% and 20\% respectively. Many of the stocks for which derivative contracts are available usually have no price limits. The stocks listed under different price bands are also shifted from one band to the other, depending on the performance of the stock in the market. In the Indian context, these shifts from one band to other are made on the basis of the volume trading done on a particular stock. In case a stock is actively traded then a constraint of $2 \%$, will definitely build a lot of volume pressure on the stock and it has to be shifted to a higher band. This phenomenon is quite evident from the fact that most of the large capitalization stocks do not fall under smaller limits as the volume traded daily is huge. The other discretion on the imposition of the limits is the predicted volatility, in case a stock exhibits a high rate of volatility, then it has to be shifted to a lower band of price constraint, so that the volatility is under a more stringent limits. However, we were not able to find any meaningful explanation on the NSE website as to how the price bands are arrived and imposed.

Price limits pre-specify the maximum range in which prices are allowed to move within a single day. The bands are typically determined by a percentage based on the previous day's closing price. Regulators or exchanges impose these price bands as a mechanism to control volatility. However, the effectiveness of these price bands is questioned in the literature. 
The main objective of this paper is to study the effectiveness of price bands on National Stock Exchange. Price bands are imposed to reduce volatility of stocks, however critics argue that price bands instead of reducing volatility merely causes volatility to spread to other subsequent days, delay price discovery and causes trading interference. This paper empirically tests the effectiveness of price bands in Indian capital markets by testing the volatility spillover hypothesis. The rest of the paper is organized as follows, section I deals with the literature review, section II deals with Data and Methodology. Section III talks about results and finally we talk about conclusion in section IV.

\section{Literature Review}

Early literature on the effects of price limits focused on future markets, for example, Brennan (1986), Ma et al. (1989), Morgan and Trevor (1997), and Berkman and Steenbeek (1998).

The proponents of price limits argue that traders tend to overreact to new information. Halting the trade give panic investors/traders time to cool off and to reassess their information. In this context, Price limits have the potential to moderate price fluctuations. The overreaction hypothesis is supported by (Ma et al., 1989; Greenwald and Stein, 1991; Kodres and O'Brien, 1994). However, the critics of price limits say that price limits has at least four problems. Namely, volatility spillover, delayed price discovery, trading interference and magnet effects.

Chung (1991) examines the price limit system in the Korean stock market and finds that there is no evidence that restrictive price limits decrease the volatility of stock prices. Chen (1993) examines the effect of varying daily price limits on stock price volatility in the Taiwan Stock Exchange. By comparing the stock volatility over three different price limit regimes, he finds that price limits do not provide a cooling-off effect on stock volatility. He also finds that price limits delay price discovery. However, Lee and Kim (1995) investigate the effect of price limits on stock price volatility using the daily stock price data of Korea Stock Exchange from 1980 to 1989 and find that price limits serve to reduce stock price volatility. Kim and Rhee (1997) examine the daily stock price data of the Tokyo Stock Exchange from 1989 to 1992 to investigate the performance of price limits. They conclude that the price limit system of the Tokyo Stock Exchange may be ineffective.

Phylaktis, Kavussanos, and Manalis (1999) assess the impact of price limits on stock volatility in the Athens Stock Exchange where price limits were imposed in August 1992. They use the ARCH/GARCH methodology to model the time-series of stock market volatility and a dummy variable to indicate the time period during which price limits are employed. Overall, they find that volatility did not increase or decrease after price limits were adopted. Kim and Limpaphayom (2000) examine the Taiwan Stock Exchange and the Stock Exchange of Thailand in an attempt to identify the characteristics of stocks that frequently hit price limits. They find that volatile stocks, actively traded stocks, and small market capitalization stocks hit price limits more often than others. Chan, Kim, and Rhee (2001) use the trade-to-trade data from the Kuala Lumpur Stock Exchange to examine the impact of a wide price limit on price discovery process. By comparing the limit-hit sample with a control sample of stocks that also experience a large price change but did not hit their limits, they find that price limits do not improve information asymmetry, delay the arrival of information, and cause order imbalance both prior to and after a limit-hit. Kim (2001) examines the relationship between price limits and stock market volatility. Using data from the Taiwan Stock Exchange during the period from 1975 to 1996, he is able to test whether price limits can moderate volatility because there were six different price limit ranges during this period. The result shows that the stock market is not less volatile when price limits are more restrictive. That is, restrictive price limits do not moderate volatility. However most recent studies of Kim etal (2013) study on the chinese stock markets conclude that price limits reduce volatilities in general. Deb et al (2016) studying data from the Tokyo stock exchange find that price limits are effective for lower limit hits and they do not find evidence for volatility spillover hypothesis. Wan etal (2018) studying for the Chinese stock markets find that price limits have a positive effect on maintaining the stability of the Chinese stock markets.

In this paper we follow the Kim and Rhee (1997) methodology to test the Volatility spillover hypothesis.

\section{Data}

The details for price limits data was procured from NSE circulars archive on the NSE website. There were 11 circulars issued by NSE in the year 2016. Circulars were issued on 5 Feb 20016, 4 Mar. 2016, 1 April 2016, 6 May 2016, 3 June 2016, 1 Jul 2016, 5 Aug 2016, 2 September 2016, 7 0ctober 20164 Oct 2016 and 2 Dec 2016. Table 1 shows the distribution of stocks with respective price bands. We ignored all stocks whose price bands didn't remain constant for the year 2016. In total we had 1297 stocks out of which 1206 stocks had price band of 20\%, 85 stocks that had a price band of $5 \%$ and there was 6 stocks for which the price band of $2 \%$ remained through out the year. 
Table 1. Price Bands

\begin{tabular}{ll}
\hline Number of Stocks & Price Band \\
\hline 6 & $2 \%$ \\
85 & $5 \%$ \\
1206 & $20 \%$
\end{tabular}

The stock price data has been sourced from the center for monitoring Indian economy (CMIE)prowess database. Prowess provides data for daily closing price, high price, low price and opening price for each stock in the sample. For lack of adequate observations lower limits are not studied in this paper Also only stocks with price limit of $20 \%$ are studied in this paper. As per Kim and Rhee (1997) three categories of stocks are considered for this study. The price limits in NSE are based on a fixed percentage of yesterday's closing price for a particular stock. Thus, we assume price limits are reached when the high price for the particular stock is greater than or equal to yesterday's closing price for a stock plus the limit price. On the days when price limit is reached, two different stock sub groups are also identified. Stock ${ }_{90}$, where stock price has reached at least $90 \%$ of price band but did not hit price limit and stock $_{80}$ where stock price has reached at least $80 \%$ of price band but does not fall into other two categories. In all

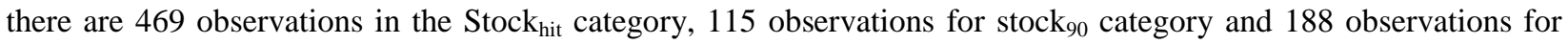
stock $_{80}$ category.

\section{Empirical Analysis}

\subsection{Volatility Spillover Hypothesis}

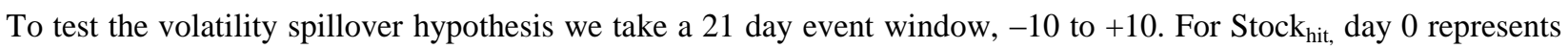
the day on which the stock has hit the limit price. For Stock ${ }_{90}$ day 0 represents the day on which stock price reaches at least $90 \%$ of limit price but failed to hit the limit, Similarly for stock 80 . The paper calculates the daily price volatility as measured in Kim and Rhee (1997), given as

$$
\mathrm{V}_{\mathrm{tj}}=\left(\mathrm{r}_{\mathrm{tj}}\right)^{2}
$$

Where $r_{t j}$, represents close-to-close returns using day $\mathrm{t}-1$ closing price and day $\mathrm{t}$ closing price for each stock $\mathrm{j}$. this measure is calculated for each of three stock groups. For evidence of volatility spillover hypothesis, the Stock ${ }_{\text {hit }}$ group should experience greater volatility during post limit days than the other subgroups. 
Table 2. Volatility Spillover

\begin{tabular}{|c|c|c|c|c|c|}
\hline \multicolumn{3}{|c|}{ Event Day Stock ${ }_{\text {hit }}$} & \multicolumn{2}{|l|}{ Stock $_{90}$} & \multirow{2}{*}{$\begin{array}{l}\text { Stock }_{\mathbf{8 0}} \\
0.412106\end{array}$} \\
\hline-10 & 0.464334 & $>>$ & 0.241028 & $<<$ & \\
\hline-9 & 0.457455 & $>$ & 0.202676 & $<<$ & 0.433657 \\
\hline-8 & 0.510205 & $\gg$ & 0.249949 & $<<$ & 0.429516 \\
\hline-7 & 0.576359 & $\gg$ & 0.273439 & $<<$ & 0.393692 \\
\hline-6 & 0.611812 & $>$ & 0.207018 & $<<$ & 0.451522 \\
\hline-5 & 0.564005 & $\gg$ & 0.270614 & $<<$ & 0.554108 \\
\hline-4 & 0.591109 & $\gg$ & 0.235255 & $<<$ & 0.530574 \\
\hline-3 & 0.645873 & $>$ & 0.251737 & $<<$ & 0.522747 \\
\hline-2 & 0.680356 & $>$ & 0.224059 & $<<$ & 0.543963 \\
\hline-1 & 1.227338 & $>>$ & 0.267507 & $<<$ & 0.997463 \\
\hline 0 & 4.366681 & $\gg$ & 0.264744 & $<<$ & 1.438309 \\
\hline 1 & 1.201131 & $>$ & 0.247087 & $<<$ & 0.637681 \\
\hline 2 & 0.7774 & $>$ & 0.244365 & $<<$ & 0.569153 \\
\hline 3 & 0.717794 & $\gg$ & 0.28475 & $<<$ & 0.547889 \\
\hline 4 & 0.673811 & $\gg$ & 0.230309 & $<<$ & 0.475169 \\
\hline 5 & 0.672552 & $\gg$ & 0.211469 & $<<$ & 0.495327 \\
\hline 6 & 0.626724 & $>$ & 0.208093 & $<<$ & 0.528396 \\
\hline 7 & 0.582486 & $\gg$ & 0.255664 & $<<$ & 0.5313 \\
\hline 8 & 0.600239 & $\gg$ & 0.325286 & $<<$ & 0.459623 \\
\hline 9 & 0.55777 & $>>$ & 0.265445 & $<<$ & 0.449965 \\
\hline 10 & 0.598767 & $>$ & 0.270376 & $<<$ & 0.438008 \\
\hline
\end{tabular}

>>Indicates that the left hand figure is greater than the right figure at $1 \%$ confidence level using wilcoxon signed rank test. Similarly, $<<$ indicates that the right hand figure is greater than the left figure at $1 \%$ confidence level using wilcoxon signed rank test.

As can be seen from table 2, the volatilities of stock subgroups shed no light on volatility spillover hypothesis. Ideally to show volatility spillover hypothesis, during the event days of 1 to 4 differences in stock volatility between Stock $_{\text {hit }}$ and stock $_{90}$ sub groups should be significant and different and on the same days stock ${ }_{90}$ and stock $\mathrm{k}_{80}$ should not be statistically significant and different, so that the spillover of volatility immediately after the event day zero can be attributed to the price limits. The results are in quite contrast to what we get to see from kim and rhee (97). Interestingly, stock ${ }_{90}$ group doesn't show much variation in volatility over the event window. Even on day 0 stock $_{90}$ does not show much volatility when compared to $\mathrm{stock}_{\mathrm{hit}}$ and $\mathrm{stock}_{80}$. Kim and Rhee (97) cautions that researchers should not be tempted to conclude that decline in the volatility of stock $\mathrm{hit}_{\text {group }}$ after day 0 should not be attributed to the price limit. Volatility declines after days of high volatility (Miller 1989. Our results are consistent with Kim et al (2013), Deb et al (2016) and Wal et al (2018) who show the price limits acts as a mechanism to stabilize markets.

\section{Conclusion}

Using the event study methodology of Kim and Rhee (97) we do not find evidence for volatility. The results could be attributed to the special characteristics of emerging markets where markets are not mature relative to developed markets and most of the companies are small in size. Further research need to be done to bring out the effectiveness of price limits in emerging markets.

\section{References}

Bhattacharya, Utpal, \& Matthew Spiegel. (1998). Anatomy of a market failure: NYSE trading suspensions (1974-1988). Journal of Business \& Economic Statistics, 16, 216-226.

Brennan, Michael J. (1986). A theory of price limits in futures markets. Journal of Financial Economics, 16, 213-233. https://doi.org/10.1016/0304-405X(86)90061-9 
Chung, Jeff, \& Li Gan. (2000). Empirical estimates of effect of price limits on limit-hitting days, Unpublished working paper, University of Texas, Austin.

Chung, Jong-Rock. (1991). Price limit system and volatility of Korean stock market, In: S.G. Rhee and R.P. Chang, eds. Pacific-Basin Capital Markets Research, 2, (Elsevier Science Publishers B.V., North-Holland), 283-294.

Chou, Pin-Huang. (1997). A Gibbs sampling approach to the estimation of linear regression models under daily price limits. Pacific-Basin Finance Journal, 5, 39-62. https://doi.org/10.1016/S0927-538X(96)00027-3

Chou, Pin-Huang, Mei-Chen Lin, \& Min-Teh Yu. (2000). Price limits, margin requirements, and default risk. $\begin{array}{llllr}\text { Journal of } & \text { Futures } & \text { Markets, } & \text { 573-602. }\end{array}$ https://doi.org/10.1002/1096-9934(200007)20:6<573::AID-FUT4>3.0.CO;2-O

Chen, Haiwei. (1998). Price limits, overreaction, and price resolution in futures markets. Journal of Futures Markets, 18, 243-263. https://doi.org/10.1002/(SICI)1096-9934(199805)18:3<243::AID-FUT1>3.0.CO;2-T

Chen, Haiwei. (2002). Price limits and margin requirements in futures markets, Financial Review 37, 105-121. https://doi.org/10.1111/1540-6288.00007

Chen, Yea-Mow. (1993). Price limits and stock market volatility in Taiwan. Pacific-Basin Finance Journal, 1, 139-153. https://doi.org/10.1016/0927-538X(93)90005-3

Deb, S. S., Kalev, P. S., \& Marisetty, V. B. (2017). Price limits and volatility. Pacific-Basin Finance Journal, 45, 142-156. https://doi.org/10.1016/j.pacfin.2016.12.002

Kim, Kenneth A. (2001). Price limits and stock market volatility. Economics Letters, 71, 131-136. https://doi.org/10.1016/S0165-1765(00)00403-1

Kim, Kenneth A., \& Piman Limpaphayom. (2000). Characteristics of stocks that frequently hit price limits: empirical evidence from Taiwan and Thailand. Journal of Financial Markets, 3, 315-332. https://doi.org/10.1016/S1386-4181(00)00009-4

Kim, Kenneth A., \& S. Ghon Rhee. (1997). Price limit performance: evidence from the Tokyo Stock Exchange. Journal of Finance, 52, 885-901. https://doi.org/10.1111/j.1540-6261.1997.tb04827.x

Kim, K.A., Liu, H. \& Yang, J.J. (2013). Reconsidering price limit effectiveness. The Journal of Financial Research, 36(4), 493-517. https://doi.org/10.1111/jfir.12021

Kodres, Laura E., \& Daniel P. O'Brien. (1994). The existence of Pareto-superior price limits. American Economic Review, 84, 919-932.

Lauterbach, Beni, \& Uri Ben-Zion. (1993). Stock market crashes and the performance of Circuit Breakers: empirical evidence. Journal of Finance, 48, 1909-1925. https://doi.org/10.1111/j.1540-6261.1993.tb05133.x

Lee, Charles M.C., Mark J. Ready, \& Paul J. Seguin. (1994). Volume, volatility, and New York Stock Exchange trading halts. Journal of Finance, 49, 183-214. https://doi.org/10.1111/j.1540-6261.1994.tb04425.x

Lehmann, Bruce N. (1989). Commentary: Volatility, price resolution, and the effectiveness of price limits. Journal of Financial Services Research, 3, 205-209. https://doi.org/10.1007/BF00122802

Greenwald, Bruce C., \& Jeremy C. Stein. (1991). Transactional risk, market crashes, and the role of circuit breakers. Journal of Business, 64, 443-462. https://doi.org/10.1086/296547

Greenwald, Bruce C., \& Jeremy C. Stein. (1988). The Task Force Report: the reasoning behind the recommendations. Journal of Economic Perspectives, 2, 3-23. https://doi.org/10.1257/jep.2.3.3

George, Thomas J., \& Chuan-Yang Hwang. (1995). Transitory price changes and pricelimit rules: evidence from the Tokyo Stock Exchange. Journal of Financial and Quantitative Analysis, 30, 313-327. https://doi.org/10.2307/2331123

Ma, Christopher K., Ramesh P. Rao, \& R. Stephen Sears. (1989). Volatility, price resolution, and the effectiveness of price limits. Journal of Financial Services Research, 3, 165-199. https://doi.org/10.1007/BF00122800

Miller, Merton H. (1989). Commentary: Volatility, price resolution, and the effectiveness of price limits. Journal of Financial Services Research, 3, 201-203. https://doi.org/10.1007/BF00122801

Phylaktis, Kate, Manolis Kavussanos, \& Gikas Manalis. (1999). Price limits and stock market volatility in the Athens Stock Exchange. European Financial Management, 5, 69-84. https://doi.org/10.1111/1468-036X.00080

Wan, Y. L., Wang, G. J., Jiang, Z. Q., Xie, W. J., \& Zhou, W. X. (2018). The cooling-off effect of price limits in the Chinese stock markets. Physica A: Statistical Mechanics and its Applications, 505, 153-163. https://doi.org/10.1016/j.physa.2018.03.066 